Volume 6 Issue 4, December 2019

Nationally Accredited Journal,

Decree No. B/4130/E5/E5.2.1/2019

\title{
Role Of Deed Land Builders Officers (PPAT) In Addressing Problem For Registration Of Transfer Property Due To Sale Of Land In East Kolaka
}

\author{
Bambang Suprayogi ${ }^{1}$, Akhmad Khisni ${ }^{2}$ and Amin Purnawan ${ }^{3}$
}

Abstract. This study aims to determine the responsibility of the Land Deed Official (PPAT) in addressing the problems of making a deed of sale of land and how the legal consequences of the public in making the deed of sale of land if found problems in the manufacturing process PPAT deed East Kolaka District. The data used in this study are primary data, secondary data and data that can support tertiary study, then analyzed with empirical juridical methods.

Based on the results of this study concluded that the role of PPAT in Kolaka East have a stake in ensuring legal certainty transitional registration of property rights to land. Legal guarantee evidenced by an authentic act, then the transition has a strong legal force (not absolute). However, due toThe lack of public knowledge relevant authorities in givingcertainty and legal protection, it is often raised issues such as land disputes and others.So should their ideal concept for the community in the form of legal counseling in growing knowledge about the importance of Land Registry as a form of awareness of legal action against the sale and purchase of land ownership before PPAT to avoid land disputes that often arise in the future. In addition, there is still much to be understood by the Land Deed Official (PPAT) and the community in the Land Registry. Conversely, if the certificate-issuing PPAT deed of sale is not in accordance with the procedure, it is charged with the responsibility PPAT legal and administrative responsibilities.

Keywords : Land Deed Official (PPAT); Buying and Selling; East Kolaka.

\section{Introduction}

Land as a gift of God Almighty the natural resources indispensable to meet the needs of human beings, either directly for life such as planting or habitation. ${ }^{4}$ Use and utilization of land should not be detrimental to the public interest, as stipulated in Article 33 paragraph (3) of the 1945 Constitution which is the constitutional basis, which specifies that:

"Earth's water and natural resources contained in it are controlled by the state and utilized for the welfare of the people"

\footnotetext{
${ }^{1}$ Student Master of Notary Program, Faculty of Law, Sultan Agung Islamic University Semarang, Email: suprayogib11@gmail.com

${ }^{2}$ Lecturer of Faculty of Law, Sultan Agung Islamic University Semarang

${ }^{3}$ Lecturer of Faculty of Law, Sultan Agung Islamic University Semarang

${ }^{4}$ Elza Syarief, 2012, Menuntaskan Sengketa Tanah Melalui Pengadilan Khusus Pertanahan, First, Gramedia, Jakarta, p. 4.
} 
Pursuant to Article 33 paragraph (3) of the Constitution of 1945, the Government determines Act Number 5 of 1960 on Basic Regulation of Agrarian called by its official acronym BAL. Interest Act stretcher establishment by the General Company, namely:

- Laying the groundwork for the formulation of the National Agrarian Law, which is a tool to bring prosperity, happiness and justice for the State and the people, especially the farmer, in the framework of a just and prosperous society.

- Laying the foundations to hold the unity and simplicity of the land law.

- Laying the groundwork to provide legal certainty regarding the rights to the land for the people entirely. ${ }^{5}$

The implementation of good land registration is the basis and the embodiment of the orderly administration in the land sector. To achieve the orderly administration of each plot and apartment units, including switching, loading and voidance

must be registered. In connection with the implementation of land registration in particular regarding transition of property rights and the provision of evidence of rights letter, then in Article 6 paragraph (2) of Government Regulation No. 24 of 1997, specifies that:

In carrying out land registration, Head of the Land Office, assisted by the Land Deed Official (PPAT) and other officials assigned to carry out certain activities in accordance with this Government Regulation Legislation and regulations are concerned.

PPAT Deed is one source of data for maintenance of land registration data, then it must be made such that it can be used as a solid foundation for the transfer of registration and the imposition of the relevant right. Therefore PPAT is responsible for checking the conditions for the validity of the legal act concerned. Among other things match the data contained in the certificate with lists that exist in the Land Office. ${ }^{6}$

PPAT Deed is one source of data for maintenance of land registration data, then it must be made such that it can be used as a solid foundation for the transfer of registration and the imposition of the relevant right. Therefore PPAT is responsible for checking the conditions for the validity of the legal act concerned. Among other things match the data contained in the certificate with the existing lists of the land office. Procedures and formalities of making authentic deed is a legal provision that force, which means that the manufacturing processes and procedures that must be followed rigorously without the slightest alongside allowed. Deviations from procedures and the procedures of the authentic act will take legal effect to the strength of evidence that deed. $^{7}$

Although the procedure for implementing the transition (transition of land rights can occur due to inheritance without a will and a legal act of transfer of rights) ${ }^{8}$ or transfer of rights over land (land rights are concerned accidentally transferred to another party ${ }^{9}$,

\footnotetext{
${ }^{5}$ Urip Santoso, 2012, Hukum Agraria Kajian Komprehensif, First, Kencana, Jakarta, p. 277

6 Boedi Harsono, Hukum Agraria Indonesia, Sejarah Pembentukan Undang-Undang Pokok Agraria, Isi dan Pelaksanaannya, (Jakarta, Djambatan, 2012), p. 507.

7 Ibid, p. 507

${ }^{8}$ Ibid, p. 329.

${ }^{9}$ Ibid, p. 330.
} 
Volume 6 Issue 4, December 2019

Nationally Accredited Journal,

Decree No. B/4130/E5/E5.2.1/2019

The times Indonesian people in general still do not fully understand what is meant by the Land Registry. It is often found in East Kolaka Regency society, in the process of transfer of rights over land they note / purchase receipt, that legal certainty is not guaranteed and without going through the PPAT as bewenang officials. Of course, many factors that cause society to transfer of land without going through the PPAT.

\section{Research methods}

In this study, the research approach used is empirical juridical approach. The combination of the nature of juridical approach and method is empirical, namely to see the reality in the field (field research) to explain the provisions of the legislation in force. ${ }^{10}$ Judicial approach is to analyze the demands of ideal values that exist in the legislation, particularly concerning PPAT role in implementing the land registration. Meanwhile, empirical approach is the fact that there is in the field such as law enforcement problems transition land ownership as a result of buying and selling in Kolaka East.

\section{Results and Discussion}

\subsection{Responsibilities Of Land Deed Official (PPAT) In response to problems Creation Deed of Sale and Purchase of Land}

The legal basis PPAT responsibility has been stipulated in Government Regulation No. 24 of 1997 which authorizes that is the attribution to the land deed official to issue certificates. In accordance with article 1 paragraph 24 PP 24, 1997, that the Land Deed Official, hereinafter called PPAT is a public official who is authorized to make certain land deed.

Accordingly, in Article 3, paragraph (1) of Government Regulation No. 37 of 1998 on the Position Rules Deed Official Land explain Deed PPAT made is deed authentic over land rights and title to the apartment unit located within the area of work. The authentic Deed is a deed in the form prescribed by law, made by or in the presence of public servants in power to it in a place where the deed was made. ${ }^{11}$ Furthermore, a certificate that is because it is not in power or not competent employees referred to above, or because of a defect in form, can not be treated as an authentic deed, however, have the power as a writing under the hand if it is signed by the parties. ${ }^{12}$

PPAT Deed is one source of data for maintenance of land registration data, then it must be made such that it can be used as a solid foundation for the transfer of registration and the imposition of the relevant right. Therefore PPAT is responsible for

\footnotetext{
${ }^{10}$ Muslan, Abdurrahman. Sosiologi dan Metode Penelitian Hukum. (Malang: UMM Press, 2009), p. 94.

${ }_{11}$ Salim HS, Teknik Pembuatan Akta Tanah Pejabat Pembuat Akta Tanah, Jakarta: Rajawali Press, 2016, p. 75

${ }^{12}$ Article 1869 Book of Civil Law Act.
} 
checking the conditions for the validity of the legal act concerned. Among other things match the data contained in the certificate with lists that exist in the Land Office ${ }^{13}$, Registration of Transfer of Rights to Land, conducted by PPAT, in accordance with the Regulation of the National Land Agency Number 1 Year 2006 on the Implementation of Regulations Title Conditions PPAT the Government Regulation No. 37 Year 1998 on the Regulation of Land Deed Official Position, which in Article 2 states $^{14}$ :

(1) PPAT charge of principal to implement part of the registration activities of land with a deed as proof he had done certain legal actions regarding land rights or Right of Ownership on Unit Housing Project, which will be the basis for the registration of changes in the registration data of land caused by works of the law.

(2) The legal actions referred to in paragraph (1) are as follows:
a. buy and sell;
b. exchange;
c. grant;
d. inclusion in the company (inbreng);
e. The distribution of rights together;
f. Award Broking / Right of Use of Land Properties;
g. Award Mortgage;
h. Imposing Counsel Award Mortgage.

Position PPAT as a public official, then PPAT prohibited from holding office or profession as an attorney or advocate, civil servants or employees of State Owned Enterprises / Region (vide Article paragraph (2) Regulation No. 37 of 1998).

The certificates represent proof of the strongest and most of one's ownership of land as stipulated in the Basic Agrarian Law (BAL No. 5, 1960). By having someone considered valid certificate occupy and possess the land and conduct legal relations and transactions against the land.

\subsection{As a result of Public Law In the Create Land Sale and Purchase Agreements If Found Problems In Making Process PPAT Deed Kolaka In East}

The importance of the position of PPAT in issuing the deed of sale requires the legal liability of the deed made. That is why PPAT should follow the procedures prescribed by the Act and various regulations related to the transfer of ownership of land and land registration. All of these procedures must be followed in order that the deed of transfer of rights made by PPAT lawful. A deed which is not in accordance with the procedures PPAT deed may pose a risk to secure rights to the land arising from or recorded on the basis of the deed. ${ }^{15}$

\footnotetext{
${ }^{13}$ Boedi Harsono, op. Cit, p. 507.

${ }^{14}$ Article 2 (1) and (2) of Government Regulation No. 37 of 1998 on the Regulation of Land Deed Official Position.

${ }^{15}$ Felix The "Perlidungan Hukum Atas Kriminalisasi terhadap Notaris", Journal of Legal Issues, Volume 46 No. 3, July 2017, p. 219.
} 
Volume 6 Issue 4, December 2019

Nationally Accredited Journal,

Decree No. B/4130/E5/E5.2.1/2019

The registration land ownership because people buy, sell Kolaka largely due to the transfer of property rights do not land on the authorities. The contributing factors is the lack of knowledge related to the Land Deed Official, high cost, because the family is very strong and the contributing factors of public awareness is very low.

Based on interviews with Drs, Z. Dachlan, B.Sc., SH., SE., M.Kn, as one resident as a Notary and Land Deed Official (PPAT) East Kolaka District, is the community should be looking for the government and the competent authorities in the transfer of property rights to land so that legal certainty is guaranteed and there are no problems later in the day. ${ }^{16}$

Generally speaking conscious or not conscious, people who are in Kolaka about buying and selling land in front of PPAT. Must first classify the life of the communities in Kolaka is Among children aged 23-59 years and Among Adults Age $>60$ Years. Among Adults $60 \%$ percent had a lot to understand about the Sale and Purchase of Land in front of PPAT of Figures $100 \%$ percent. Among adults because they have the education that could be considered very good. While age is $>60$ years and older are still many who are not educated at all and the level of understanding on the Sale and Purchase of Land in front of PPAT $70 \%$ of the $100 \%$ percent. so that the problem occurred after the transfer of ownership of the land to the heir to the future.

A case about the process behind the name of the certificate that often occurs in the county Kolaka due to buying and selling under the counter. When the A buy land area of 10000 square meters to a Balinese transmigration, transaction takes place by mutual agreement of both parties. The incident occurred about 20 years ago with no reverse process behind the name on certificate. After the A's death the ownership of the land which falls to the disinherited son. The short story when his son wanted to return the name of the certificate for the purposes of bank loans, PPAT find obstacles where the name on the certificate is different from the identity of the original owner of the land. The name on the certificate stamped 'Pan Jagri' temporary identity certificate owner beginning named 'Made Sumerta'. After the existence find pass between them and the issues involving the government does not know at all chronology of buying and selling under the hand. Finally after crosscheck at the village level, it turns out the name on the certificate of 'Pan Jagri' is the same person as the identity of 'Made Sumerta'. Village authorities immediately made a statement related to differences in the name.

These problems occur when Made Sumerta receive transmigration land division, at that time he was represented by the head of the group trans to the management of property rights on land that only includes only the nickname of 'Pan Jagri'. Pan jagri itself in Bali means father Jagri term, which is a subsidiary of a Made Jagri Sumerta.

This is the case which often occurs East Kolaka District, which often involve the government and all relevant parties related agreement without involving the purchase

\footnotetext{
${ }^{16}$ Interview, Drs. Z. Dachlan., B.Sc., SH., SE., M.Kn, Notaris dan Pejabat Pembuat Akta Tanah, 23 November 2019
} 
of land at the beginning of the transaction as well PPAT not immediately behind the name. So that it is a vulnerability in the future to cause disputes.

The lack of knowledge about the role of the Land Deed Official makes people in Kolaka not make the process of selling the appropriate legal procedures. besides the frequent complaints related to the administration that he says is too expensive for the completion of the registration process on Land made public Kolaka buying and selling under the hand. This occurs by reason of the level of charge is issued when using an authorized officer or Officer Deed Land was very costly so that people can not afford to pay it. And those that say for buying and selling they do it only to the family. So they think in the future there could be no problems and although there is a problem they will resolve amicably. In terms of percentage ratio of the unconscious and conscious people of the sale and purchase of land in front of PPAT, already $65 \%$ percent of the merging among adults 23 59 years and $>60$ years and above are regarded schools. Then the remaining $35 \%$ percent are sometimes still new and needed adjustments to the importance of awareness of legal order in force by government programs. Things need to be put how the public aware of the legal order in practice going back to the common good. So broadly interpreted that conscious rice and legal order in the society, are at society itself. Duties and jurisdiction only as remind and protect the society will importance rule of law.

Position PPAT as a public official in the process of issuing certificates of land ownership which can be regarded as official mediator of interests between the holders of property rights on land that wishes to obtain a certificate with the Land Office and determines all the duties and responsibilities in implementing part of land registration activities with a deed as proof of legal acts certain has done over land rights, especially property rights on land located within the area of work.

Under the rules of procedure of registration of land which has been set by the government. It is expected that people carrying out the transfer of land rights. Thereby reducing the effects of disputes over land dispute

Generally, an ideal concept for People East Kolaka in order to carry out the land purchase with PPAT or competent authority to ensure legal certainty deeds community in the civil field. Then the government must be proactive and act as a driving force and as a protector of major public legal action.

In the case of registration of land known today as defined in Regulation No. 24 of 1997 on Land Registration is done through the registration systematically that is based on a work plan and implemented in the areas specified by the Minister, in addition to land registration sporadic, namely in the case of a rural / village have not been zoned land registration systematically. How to register the land in question is constantly improved in view of the fact a lot of requests from the public to sign up individually as well as ground together to obtain legal certainty on the status of its land rights.

According to Article 32 PP 24 of 1997 on Land Registration, stated:

(1) The certificate is a proof of rights letter that enactment as a strong evidence of the physical data and juridical data contained in it, all the physical data and juridical data contained in the letter of existing data measurement and land book.

(2) In the event that a plot has been legally issued certificates on behalf of the person or legal entity Things that should be done by the government to the rule of law society is 
Volume 6 Issue 4, December 2019

Nationally Accredited Journal,

Decree No. B/4130/E5/E5.2.1/2019

legal counseling to the community through the approach between government and society, dissemination of legal awareness related to transfer ownership of land on people's lives and logging and land book maker land owners.

From the discussion above can pull the conclusion that the necessity of seriousness by the government in implementing these programs to make people aware of the actions legally. Because that's the ideal concept that evokes the power of public awareness for the rule of law in his actions were properly carried out.

\section{Closing}

\subsection{Conclusion}

- Land Deed Official (PPAT) responsible for the overall manufacture of the deed of sale both procedures, mechanisms, and procedures.

- PPAT role in Kolaka East have a stake in ensuring legal certainty for land registration. Legal guarantee evidenced by an authentic act, then the transition has a strong legal force (not absolute). However, due toThe lack of public knowledge relevant authorities in giving certainty and legal protection, it is often raised issues such as land disputes and others.

\subsection{Suggestion}

- To create legal certainty in land transfer and avoid the increasing number of disputes or cases of litigation, it should supervise the PPAT should be tightened. With tighter supervision of PPAT expected misuse and diversion procedures procedures will be addressed.

- need forConcept ideal for society in the form of legal counseling in growing knowledge about the importance of Land Registry as a form of awareness of legal action against the sale and purchase of land ownership before PPAT to avoid land disputes that often arise in the future. In addition, there is still much to be understood by the Land Deed Official (PPAT) and the community in the Land Registry. Conversely, if the certificate-issuing PPAT deed of sale is not in accordance with the procedure, it is charged with the responsibility PPAT legal and administrative responsibilities.

\section{References}

[1] Boedi Harsono, 2012, Hukum Agraria Indonesia, Sejarah Pembentukan UndangUndang Pokok Agraria, Isi dan Pelaksanaannya, Content and Implementation, Jakarta: Djambatan.

[2] Elza Syarief, 2012, Menuntaskan Sengketa Tanah Melalui Pengadilan Khusus Pertanahan, Jakarta: Gramedia.

[3] Muslan, Abdurrahman, 2009, Sosiologi dan Metode Penelitian Hukum, Malang: UMM Press. 
[4] Salim HS, 2016, Teknik Pembuatan Akta Tanah Pejabat Pembuat Akta Tanah, Jakarta: Rajawali Pers.

[5] Urip Santoso, 2012, Hukum Agraria Kajian Komprehensif, Jakarta: First Kencana.

\section{Other Sources:}

[1] Law No. 5 of 1960, the Basic Agrarian Law.

[2] Government Regulation No. 24 of 2007 on Land Registration.

[3] Government Regulation No. 37 of 1998 on the Position Rules PPAT

[4] Negra Regulation of the Minister of Agrarian Affairs / Head of BPN No. 3 year 1997 on the implementation of Government Regulation No. 24 of 1997.

[5] Article 2 (1) and (2) of Government Regulation No. 37 of 1998 on the Regulation of Land Deed Official Position.

[6] Article 1869 Book of Civil Law Act.

[7] Felix The "Perlidungan Hukum Atas Kriminalisasi terhadap Notaris ", Journal of Legal Issues, Volume 46 No. 3, July 2017. 